\title{
Understanding of Humanistic Spirit in Urban Sculpture
}

\author{
Yanjun Jiao ${ }^{1, *}$
}

\author{
${ }^{1}$ Northwest University, Xi'an, Shaanxi, China \\ *Corresponding author. Email: 838856604@qq.com
}

\begin{abstract}
This paper first explores the internal connection between "Tao" (ideal method) and "Qi" (a definite thing) in Chinese traditional humanistic spirit and the free style in Chinese artistic spirit. Then, by pointing out that sculpture is the carrier of cultural spirit, this paper analyzes the reasons for the lack of humanistic spirit in Chinese traditional sculpture, and emphasizes that "people-oriented" humanistic spirit gradually appeared in Chinese sculpture art at the beginning of last century. Finally, it points out that through the efforts of several generations of sculptors, Chinese urban sculpture not only inherits the ancient sculpture tradition, but also excavates the humanistic connotation. Excellent urban sculptures are always based on the local artistic language, focusing on the connection with the traditional context, and at the same time reflecting the contemporary intellectuals' keen attention to the social humanity.
\end{abstract}

Keywords: humanistic spirit, urban sculpture, national language

\section{INTRODUCTION}

An influential urban sculpture carries not only the spiritual civilization of the local people, but also the soul of a city - civilization process, humanistic spirit and individual style. The development course of Chinese urban sculpture is only one hundred years or so. After experiencing the collision of eastern and Western cultures, the development of Chinese sculpture has been a long and tortuous process from the denial of tradition and overall westernization to the continuous exploration and discovery of the artistic spirit of traditional sculpture. With the deepening of research, Chinese modern and contemporary sculpture gradually reflects the subjectivity and cultural confidence of the culture in two aspects of modeling language and spiritual connotation, while the expression of Chinese urban sculpture on the humanistic spirit is also gradually bright and clear.

\section{THE RELATIONSHIP BETWEEN "TAO" AND "QI" AND THE CHINESE ARTISTIC SPIRIT}

\section{A. The relationship between "Tao" and "Qi" and artistic creation}

Grasped as a whole, the Chinese traditional culture has humanistic spirit as its main and most distinct feature, with a people-centered core ${ }^{1}$. Chinese humanistic spirit focuses not only on the ontological

See Lou Yulie. Humanist Spirit in Chinese Culture, Journal of Peking University (Philosophy \& Social Sciences), 2015, 1st issue, p. 8. existence of human being (body and mind), but also on the relationship between human being and society. In the traditional academic field, the humanities and astronomy are closely linked to the pursuit of the Taoist unity of man and heaven. Therefore, humanistic spirit pays attention to the world with holistic thinking, guides the physical objects with metaphysical Tao, and connects the academic spirit with the aesthetic realm.

It is said in "Zhouyi . Xici I", "That which is antecedent to the material form is known as an ideal method (Tao); and that which is subsequent to the material form is known as a definite thing (Qi). The effect of the two, leading to the sympathia and civilization of people and to generalize such change is called 'tong' (thorough) ${ }^{2}$. Ancient sages divided traditional Chinese learning into two levels of "Tao" and "Qi". In the traditional art, its aesthetic realm is connected with the academic spirit, and its method-skill relationship is similar to the relationship between Tao and Qi. Traditional Chinese art emphasizes that the creator grasp the Tao through skill, and the art with skill but without Tao is only the skill of the craftsman, which cannot reach the highest state of art. That is to say, the creator should fit with the object in spirit and emphasize that reproduction should be subordinated to expression in form and language, that is, in artistic creation, Tao must command skill.

The highest realm of traditional Chinese learning is the "Tao", which embodies heaven, earth and man. It is

See Huang Shouqi, Zhang Shanwen. Translation and Annotation of "the Book of Changes" (Shanghai Classics Publishing House, 2001) 
the noumenon that dominates all objects and knowledge, and also the important manifestation of traditional Chinese humanistic spirit ${ }^{3}$. However, in today's highly developed material civilization, the pursuit and dependence of material has become a common situation faced by urbanites. And it has also formed a kind of materialized aesthetic idea.

\section{B. The "free style" throughout the development of Chinese art}

In traditional Chinese art, free style is one of the forms of pursuing Tao. Chinese traditional art has always paid attention to free style, which is to express the mind and reflect the artistic conception. As an aesthetic pursuit, free style is intended to reveal the true meaning of art. It can be said that any artistic work with the connotation of traditional Chinese culture can be called "free-style work as long as it grasps the interest of natural objects, expresses the feelings of the author and the humanistic value based on it. This is the broad understanding of free style.

Taking traditional calligraphy as an example, the art of calligraphy is almost abstract, which is realized by seeking morphological changes in time and all things. "Being based on the heart of heaven and earth", which is the natural catharsis of the author's desire and an expression of life emotion. Therefore, "there is no such a thing in the world that cannot be expressed by cursive script" is regarded as the highest realm of Chinese art. Cursive script is the most direct way for the author to express feelings and show heart. It can best reflect the author's thoughts and emotions.

When painting developed into the period from Song to Yuan dynasties, especially in the Ming Dynasty, freehand brushwork and freehand brushwork based on "Tao" were integrated into painting, making painting more free and comfortable. Freehand brushwork, which integrates the author's emotions and personal thoughts, makes the lines more open and free. Freehand brushwork focuses not only on the free expression form, but also on the creator's inner content expressing from inside to outside, which is exactly what Zhuangzi called "heaven and earth are born together with me, and all things are one with me". Such expressions are at the heart of humanism.

\section{THE HUMANISTIC SPIRIT IN CHINESE SCULPTURE}

\section{A. Sculpture as a carrier of cultural spirit}

Sculpture is not only one of the symbols of national culture, but also an indispensable part of national

See Yuan Jixi. Study on the Humanistic Spirit of Traditional Chinese Scholarship. Social Science Front, No.4, 2013, pp. 2-3. cultural heritage. Sculpture not only tells the development history of a country or a nation, but also embodies the spirit and tradition of a nation. It represents the spiritual outlook of every country and every period of history, reflects the thoughts, concepts and beliefs of people from ancient times to the present, and also shows the values and aesthetic tastes of different times and groups. Sculpture also sublimates from the original practical function to the carrier of spirit and culture, especially the urban sculpture standing in the public space of every city.

Urban sculptures are generally placed in urban public spaces (such as stations, parks, etc.), and also appear in public places with humanistic spirit (such as cultural celebrity memorial hall, museum, art gallery, etc.). The theme of urban sculpture is generally related to the local history, folk stories and outstanding figures, so it reflects the human history and spiritual outlook of a city, which not only beautifies and improves the urban appearance, but also exerts a subtle influence on the aesthetic sentiment of citizens.

An excellent urban sculpture can not only enhance the readability, identification and publicity of a city, enhance people's perception and experience of local culture and history, but also improve the city's living environment and cultural landscape. In a word, publicness and civic-orientation are the first principles to be followed in the creation of urban sculptures and are also determined by the nature of sculpture, namely, the humanistic spirit.

\section{B. The development and status of Chinese ancient sculpture}

Chinese ancient sculpture which flourished in the Qin and Han dynasties has two different modes of expression, realism and freehand brushwork. Especially in the Han Dynasty, the "free style" appeared in ancient Chinese sculpture, which was consistent with Chinese aesthetic thoughts. The "free-style" sculpture in the Han Dynasty shows the artistic language of Chinese sculpture with the strongest and most distinct character. The stone carvings in front of Huo Qubing's tomb are representative of this. A slight carving was made based on its natural appearance, which brings the beauty of the image to the fore. This is different from the TerraCotta Warriors in the Mausoleum of the First Qin Emperor, and is rare in the history of Chinese and foreign sculpture. However, since the Northern and Southern Dynasties, the prevalence of Buddhism had made Buddhist statues the mainstream of Chinese sculpture, and the sculpture art lost the beauty of "free style" presented independently at first, and gradually became the subordinate of religion and politics. As late as the Ming and Qing dynasties, sculpture art became the accessory of architecture and the qinggong (an indoor decoration placed on a desk for viewing) in a 
study, appearing in the architectural decoration of royal gardens

In the traditional Chinese art, sculpture, as the main artistic category, seems to lack the proper connection with the humanistic spirit. There are two main reasons for this phenomenon. First of all, from the perspective of function, traditional Chinese sculpture has obvious social utility. In addition to technological sculpture to meet the needs of practical life, there are two major categories of sculpture that serve funeral and religion. Among them, technologic sculpture emphasizes decoration, while funeral and religious sculpture show limited and declining humanistic care this-worldly. Although portrait sculpture was popular in Tang Dynasty, it failed to form a tradition of portrait sculpture. Therefore, humanistic spirit cannot be presented in the absence of objects.

Secondly, the status and educational level of ancient sculpture artisans lead to their lack of independent aesthetic status. In contrast, due to the active participation of the literati in all dynasties, Chinese painting and calligraphy had their own mature theoretical systems; yet the modeling and theory of ancient sculpture were attached to painting to a certain extent. It was difficult for ancient craftsmen to form aesthetic consciousness in their creations, and its limitations made it difficult for humanistic spirit to be embodied even if the object exists.

\section{C. "People-oriented" humanistic spirit in the introduction of sculpture}

Western countries, mainly in Europe, have a long history of urban sculpture. They place sculptures with humanistic sentiments in important public places, especially in city squares where citizens gather, so as to record the history of a country, a nation or a group, as well as important events that influence the great changes of the times.

In "Marx and Engels On Literature and Art", Engels discussed the status of "Renaissance" in human history as follows: "It was the greatest progressive revolution that mankind had ever seen, an age that required giants and gave them birth - giants in power of thought, in passion, in character, in versatility, and learning." 4 Michelangelo's "David", one of the architects of the Renaissance, immortalized his place in art history, and two replicas still stand in public spaces in Florence. In the field of Western sculpture in the 19th century, Rodin became an innovator with epoch-making significance. His sculptures became a bridge between the past and the present, "restoring the significance of the sculpture value itself", and made the sculpture art

See (Germany) Marx and Engels. Marx and Engels On Literature and Art. Trans. Cao Baohua. China Social Sciences Press, 1982, p. 279. begin to change to the direction of modern art. More importantly, his works showed a strong humanistic spirit, which was inherited and carried forward by his successors. In the early 20th century, Bourdelle which was a disciple of Rodin taught some of the Chinese students who went to France to study digital art. French artistic concept has deeply influenced Chinese students who went to France.

In 1929, a sculptor of the Jiang Xiaojian, who returned from study abroad, created a bronze statue of Mr. Sun Yat-sen; later, Li Jinfa who returned from France made statues for educator Cai Yuanpei and other celebrities; Liu Kaiqu, who also returned to China from France, finished the "The Monument to the Fallen Soldiers of the Anti-Japanese War in the Incident of January in Shanghai", which became the symbol of the rise of modern Chinese urban sculpture. The emergence of these urban sculptures reflects the awakening of the nation and the needs of modern urban development, and injects a new spirit into the development of Chinese culture.

Urban sculpture appeared in the Republic of China, was basically a way for artists to learn from western sculpture to intuitively represent historical figures and events. From the 1950s, sculptors studying in the Soviet Union have created a large number of sculptures reflecting the construction of new China in a revolutionary realist way. Realistic and commemorative sculpture, in an independent form, entered the public space and became a milestone in the history of Chinese sculpture. Since the reform and opening up, many problems have emerged in the construction and development of urban sculpture, which affect the construction of urban culture. This is mainly reflected in two aspects. First, the production of rough, patterned geometric sculptures ran rampant; they have no formal beauty, let alone spiritual connotation. Secondly, the creation of some urban sculptures began to break away from the social reality, excessively expressing personal form language and lacking the communication of public spirit. Although sculpture belongs to the plastic art, if artists only regard form as the core, their works can hardly meet the requirements of urban sculpture. Especially in the period of social transformation and multiple value orientations, the core of urban sculpture should be to carry forward the noble and upward humanistic spirit 5 . 


\section{THE CONSTRUCTION OF HUMANISTIC SPIRIT IN CONTEMPORARY URBAN SCULPTURE}

\section{A. The connection between contemporary sculpture and traditional culture}

In The book of "Laozi", it is said: "Thirty spokes cooperate with one hub; it is because of the empty heart of the hub that they can function as a vehicle. To make pottery with clay, people have to empty the vessel; it is the empty space in it that can make a utensil. To build a house, people must beat away doors; it is because of the empty space on the wall that the house can be used as a house. Therefore the things in corporeal form exist for benefits, and those in intangible forms for use value." 6 In Chapter 11, Laozi makes a figurative analogy of "existence between to be or not to be" from the perspective of speculation. The purpose is to criticize the behavior of people clinging to the tangible material world and abandoning the spiritual pursuit. As far as sculpture is concerned, the lack of humanism impedes its progress.

In modern times, humanistic spirit, as the cultural gene of Chinese sculpture, has changed from recessiveness to dominance in the "impact-response" to Western traditional sculpture. The sculpture language based on native language gradually formed and developed. In terms of modeling language, the works of modern and contemporary sculptors such as Xiong Bingming, Wu Weishan and Chen Yungang have broadened the scope of reference of sculpture from traditional art. Importantly, the artistic conception conveyed by their works shows that they do not draw reference from traditional culture and art passively, but actively use the inherent observation and feeling ways behind them, as well as creating through inheriting the concepts related to time and space. Therefore, their works are destined to be infused with the humanistic spirit of traditional Chinese culture. In the macro context of traditional Chinese culture, they clearly understand the importance of humanistic spirit throughout various artistic categories for sculpture. Humanistic spirit is the soul of a nation and the characteristic of national character.

As an excellent sculpture work, its modeling style and spiritual connotation must be unified. In China, freehand sculpture may be one of the proper forms to reveal the humanistic spirit naturally. Through the efforts of several generations of sculptors, the free-style character in ancient sculptures has been continuously excavated and refined. Due to the different times, regions and academic backgrounds, different sculptors have expressed their understanding and reference to the

\footnotetext{
6 See Chen Guying. Laozi's Annotation, Translation and Commentary on Laozi, Zhonghua Book Company, 1984, p. 102.
}

freehand nature of ancient sculptures in their works from different angles.

\section{B. Contemporary sculpture and the embodiment of the spirit of the times}

The rise of urban sculpture inevitably requires that its shape can fully display the humanistic spirit in the public space, which exists in the space where it is located, including both tangible physical space and intangible humanistic space. This is the decisive factor for the success of urban sculpture. Facing the current cultural context of Chinese society, how to make urban sculptures possess strong humanistic spirit, distinctive personality and endow them with humanistic consciousness is a problem that every sculptor should think about.

The first should be the sculptor's attention to social reality. Chinese sculptors began to pay attention to the reality, and the artistic works should have temperature and emotion, traces of "human" and humanistic spirit, otherwise it is just a cold material and form. For example, "A Day in the Life of Shenzhen People", designed by Shenzhen Sculpture Institute, is a good work of humanistic spirit to show the concern of ordinary people in the society. In addition, the critic Yin Shuangxi said this when talking about the development of contemporary sculpture, "Sculptors' concern for the social margins and vulnerable groups is still a humanistic concern of artists."

The second should be the focus on the characteristics and personality of the sculpture itself. Sculptors have dual roles as both intellectuals and experts, and they begin to have the sense of mission when they create. They express the realistic situation and reflect the spirit of the times through concrete practice. Especially in the creation of figure sculpture in public space, sculptors need to fully grasp the appearance description, life experience and historical deeds of the target characters through recorded documents, outline the character images with personality characteristics, make bold choices, discard the rough and preserve the essence, sublimate the distinct personality characteristics of the target, and excavate the inner spirit of the characters. In this way, they can achieve the perfect unity of the form and spirit of the molded objects in their works.

There is a famous statue of Mao Zedong at Orange Island head in Changsha. Compared with the stylized sculptures of Mao Zedong all over the country, this work highlights its unique personality. It depicts a statue of Mao Zedong with flowing hair, handsome face and deep eyes. Mao Zedong had "slicked back hair" when he was in Guangzhou, before cutting it short. Therefore, in shaping the image of Mao Zedong in 1925 , the creator chose this hairstyle to show the style of the young Mao Zedong, who "proposed his thoughts 
and suggestions on state affairs with inspiring the characters", and to reflect his most personalized appearance. Taking Wu Weishan's freehand sculpture as an example, he has created many celebrities in Chinese history with his unique approach. These historical figures are unfolded according to the times, society and personal characters, expressing a mentality and attitude of Chinese cultural celebrities, which also includes political factors, power factors and some people's self-consciousness.

Moreover, in order to continue the historical context, urban sculptures should be reconstructed in combination with the characteristics of the new era, reflecting the cultural character and spiritual core of a city, and making it a cultural symbol of the city. The sculpture set in the open space of the city has an interactive relationship with the public. Therefore, the works should consider the relationship between the sculpture works and the urban context, the nature of the place, and the spatial pattern, and should have social and public cultural orientation. Taking for another example, Xiong Bingming's "Willing Ox" holds its head high on the ground between two high-rise buildings. Although the image created is a cow, it is regarded as "the self-knowledge of intellectuals of the 20 th century generations". From a larger point of view, the sculpture is installed in the original campus of Nanjing University as the centennial anniversary, which is linked with more historical and humanistic meanings.

In international cultural exchanges, artistic communication is intuitive and efficient, "which is an important way to shape and enhance national image". Specifically in the field of sculpture, this requires sculpture works to meet the requirements of two aspects. First of all, it requires the works to have the consciousness and confidence of traditional Chinese culture and art, and its artistic language has completed the transformation of contemporary; second, it emphasizes that the works should reflect the subjectivity of Chinese culture.

\section{CONCLUSION}

Urban sculpture is located in the public space of the city, carrying many functions that easel sculpture does not have. Creating humanistic environment is one of the functions of urban sculpture, which includes cultural psychology, social consciousness, characteristics of the times and aesthetic taste. Every city has its specific regional culture and collective memory, and the humanistic spirit gathered by such culture and memory can arouse the resonance of viewers and make them feel the sense of identity. These are the sources of inspiration for sculptors. In the process of creation, sculptors focus on exploring the potential collective memory and space-time publicity of the city, and show the concrete humanistic spirit connotation through the artistic form of urban sculpture.

An excellent urban sculpture should not only be an independent work of art, but also reflect the historical features, context and regional culture of the city where it is located, and interpret the history and spirit of the city. The construction of contemporary urban sculpture must carry forward the humanistic spirit built on the basis of traditional culture, and on this basis, construct the humanistic spirit of the new era. Before facing the new opportunity of the development of the times, the humanistic spirit of the new era is to sort out and inherit the excellent traditional culture. With the country's investment and vigorous promotion in cultural undertakings, urban sculpture can not only improve the soft power of cities and countries, but also further comply with the development of its own laws. For the integration of national culture and contemporary culture, there is bound to be a kind of conscious integration, rather than deliberate imitation and grafting.

\section{References}

[1] Wu Weishan. On Sculpture. China Cultural and Historical Publishing House, 2017. (in Chinese)

[2] Huang Shouqi, Zhang Shanwen. Translation and Annotation of "the Book of Changes" (Shanghai Classics Publishing House, 2001). (in Chinese)

[3] Yuan Jixi. New History of Chinese Literary Criticism. China Renmin University Press, 2014. (in Chinese)

[4] (Germany) Marx and Engels. Marx and Engels On Literature and Art. Trans. Cao Baohua. China Social Sciences Press, 1982. (in Chinese)

[5] Lou Yulie. The Fundamental Spirit of Chinese Culture. Zhonghua Book Company, 2018 (in Chinese)

[6] Chen Guying. Laozi's Annotation, Translation and Commentary on Laozi, Zhonghua Book Company, 1984. (in Chinese) 